\title{
Leaf and stem microscopic identification of Tithonia diversifolia (Hemsl.) A. Gray (Asteraceae)
}

\author{
Márcia do Rocio Duarte*, Cláudia Bonissoni Empinotti
}

\author{
Laboratory of Pharmacognosy, Departamento f Pharmacy, Federal University of Paraná
}

\begin{abstract}
Tithonia diversifolia (Hemsl.) A. Gray is an Asteraceae shrub, popularly known as Mexican sunflower and cultivated for ornamental and therapeutic uses in different countries. In folk medicine, it is of value for treating diabetes, malaria and infectious diseases. These indications have been corroborated by various pharmacological assays. Given the lack of data on anatomical aspects of $T$. diversifolia, this work aimed to investigate the leaf and stem microscopic characters of this medicinal plant and potential vegetal drug. Samples of mature leaves and young stems were sectioned and stained. Histochemical tests and scanning electron microscopy were also performed. The leaf has anomocytic stomata on both sides, dorsiventral mesophyll and several collateral vascular bundles arranged as a ring in the midrib. The stem shows angular-tangential collenchyma, an evident endodermis and sclerenchymatic caps adjoining the phloem. The main characters for anatomical identification are the different types of trichome (nonglandular, capitate and non-capitate glandular), the midrib features and the localization of the secretory ducts near the vascular system.
\end{abstract}

Uniterms: Tithonia diversifolia/pharmacognosy. Tithonia diversifolia/anatomical characters. Medicinal plants. Mexican sunflower.

Tithonia diversifolia (Hemsl.) A. Gray é um arbusto da família Asteraceae, popularmente conhecido como girassol-mexicano e cultivado como ornamental e medicinal em vários países. Tradicionalmente, é usado no tratamento de diabetes, malária e doenças infecciosas. Essas indicações têm sido corroboradas por diversos ensaios farmacológicos. Em razão das escassas informações sobre aspectos anatômicos de T. diversifolia, este trabalho objetivou investigar os caracteres microscópicos foliares e caulinares dessa planta medicinal e potencial droga vegetal. Amostras de folhas adultas e caules jovens foram fixadas, seccionadas e coradas. Testes histoquímicos e microscopia eletrônica de varredura foram também realizados. A folha apresenta estômatos anomocíticos em ambas as superfícies, mesofilo dorsiventral e vários feixes vasculares colaterais dispostos em círculo na nervura central. O caule exibe colênquima angular-tangencial, endoderme nítida e calotas esclerenquimáticas apostas ao floema. Os principais caracteres para a identificação anatômica são os diferentes tipos de tricoma (tector, glandular capitado e não capitado), os aspectos da nervura central e a localização dos dutos secretores nas proximidades do sistema vascular.

Unitermos: Tithonia diversifolia/farmacognosia. Tithonia diversifolia/caracteres anatômicos. Plantas medicinais. Girassol-mexicano.

\section{INTRODUCTION}

Tithonia diversifolia (Hems1.) A. Gray (Asteraceae, tribe Heliantheae) (Figures 1A, 1B) is a prolific shrub, perennial and erect, native to Mexico and Central

"Correspondence: M. R. Duarte. Departamento de Farmácia, Setor de Ciências da Saúde, Universidade Federal do Paraná. Av. Pref. Lothário Meissner, 632 Jardim Botânico - 80210-170 - Curitiba - PR, Brazil. E-mail: marciard@ufpr.br
America, and introduced in Africa, Australia, Asia and South America (Duke, 1982). It is widely cultivated as an ornamental shrub and for its medicinal value in different regions where it is commonly known as Mexican sunflower or tree marigold, as well as "nitobegiku" (Hui, Tang, Go, 2009).

In folk medicine, the aerial parts of $T$. diversifolia are of value for the treatment of diabetes (Hui, Tang, Go, 2009), malaria (Njoroge, Bussmann, 2006a) and 

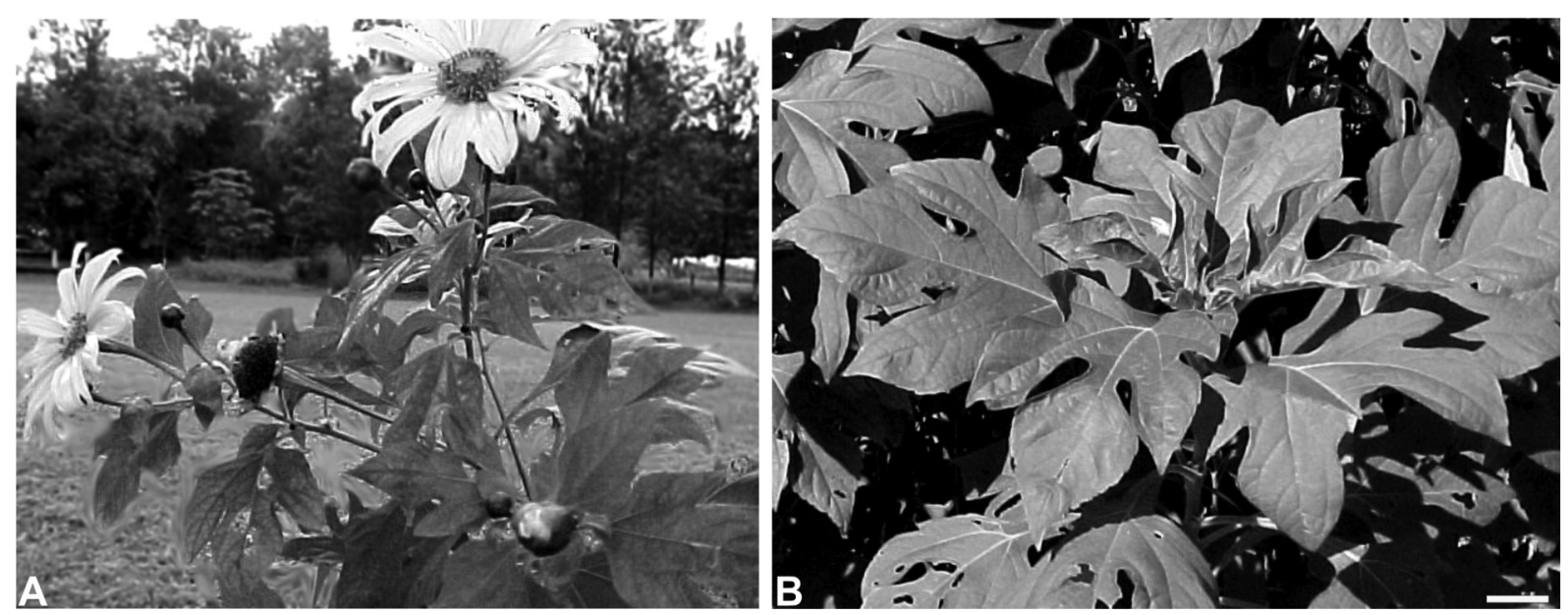

FIGURE 1 - A, B - Tithonia diversifolia (Hemsl.) A. Gray: A. Reproductive apical branches; B. Leaves. Bar $=2 \mathrm{~cm}$.

infectious diseases (Heinrich et al., 1998; Njoroge, Bussmann, 2006b; Maregesi et al., 2007). The species is of particular interest for phytomedical and health care research since it has shown diverse pharmacological activities, such as antiplasmodial (Goffin et al., 2002; Madureira et al., 2002; Elufioye, Agbedahunsi, 2004; Maregesi et al., 2009; Muganga et al., 2010), antiamoebic (Tona et al., 1998; 2000), antiviral (Cos et al., 2002; Chiang et al., 2004), anti-inflammatory (Rüngeler et al., 1998; Owoyele et al., 2004) and antidiabetic (Miura et al., 2002; 2005). Therefore, it has potential to become a reference vegetal drug.

Concerning the phytochemical analysis, the nonvolatile fractions of $T$. diversifolia are a rich source of flavonoids and sesquiterpene lactones (Pereira et al., 1997; Gu et al., 2002; Kuroda et al., 2007; Ambrósio et $a l ., 2008)$, while the essential oil comprises predominantly monoterpene hydrocarbons, such as $\beta$-ocimene, $\alpha$-pinene and limonene (Gbolade, Biondi, Ruberto, 2008).

Although many studies on $T$. diversifolia have been carried out in different research fields, there are few reports on its botanical investigation. The studies available focused on trichome aspects (Sasikala, Narayanan, 1998) and the secondary thickening pattern of the stem (Liasu, Ogunkunle, 2007). Thus, the aim of the present work was to provide data for microscopic identification of this medicinal species.

\section{MATERIAL AND METHODS}

Samples of Tithonia diversifolia (Hemsl.) A. Gray, Asteraceae were collected from at least five specimens grown in a sunny area in Palotina, a city in western Paraná, Brazil, at coordinates $24^{\circ} 17^{\prime} \mathrm{S}$ and $53^{\circ} 40^{\prime} \mathrm{W}$, and an altitude of $290 \mathrm{~m}$ in height, in December 2004. A voucher was lodged as MBM 293886 at the Herbarium of the Museu Botânico Municipal de Curitiba, Paraná, Brazil.

The microscopic analysis (anatomy) was carried out using mature leaves and young stems, obtained $5-20 \mathrm{~cm}$ from the shoot apex, fixed in FAA70 (Johansen, 1940) and kept in 70\% (v/v) ethanol (Berlyn, Miksche, 1976). The examined leaf region was the lower third of the blade and petiole. Semi-permanent slides were prepared with the fixed material sectioned transversely and longitudinally freehand and stained with astra blue and basic fuchsine (Roeser, 1972). Permanent slides were prepared with the fixed material embedded in glycol-methacrylate, sectioned using a rotary microtome, stained with toluidine blue (O’Brien, Feder, McCully, 1964) and mounted in synthetic resin (Kraus, Arduin, 1997).

Histochemical tests were performed using the following reagents: aqueous solution of ferric chloride for detecting phenolic compounds (Johansen, 1940), lugol for starch grains (Berlyn, Miksche, 1976), hydrochloric phloroglucin for lignin (Foster, 1949), Sudan III for lipophilic substances (Sass, 1951) and diluted solution of sulphuric acid for oxalate and carbonate calcium crystals (Oliveira, Akisue, 1997).

For scanning electron analysis, leaf fragments were fixed, dehydrated in a graded ethanol series and, using the $\mathrm{CO}_{2}$ critical point procedure, gold coated and examined in a high vacuum (Souza, 1998).

\section{RESULTS}

In surface view, the leaf blade has epidermal cells with thin anticlinal walls, which are sinuous in the intervein region (Figures 2A, 2B) and polygonal on the veins. A slightly striated cuticle covers the epidermis (Figure $2 \mathrm{C}$ ), and anomocytic stomata (Figure 2B) are present 

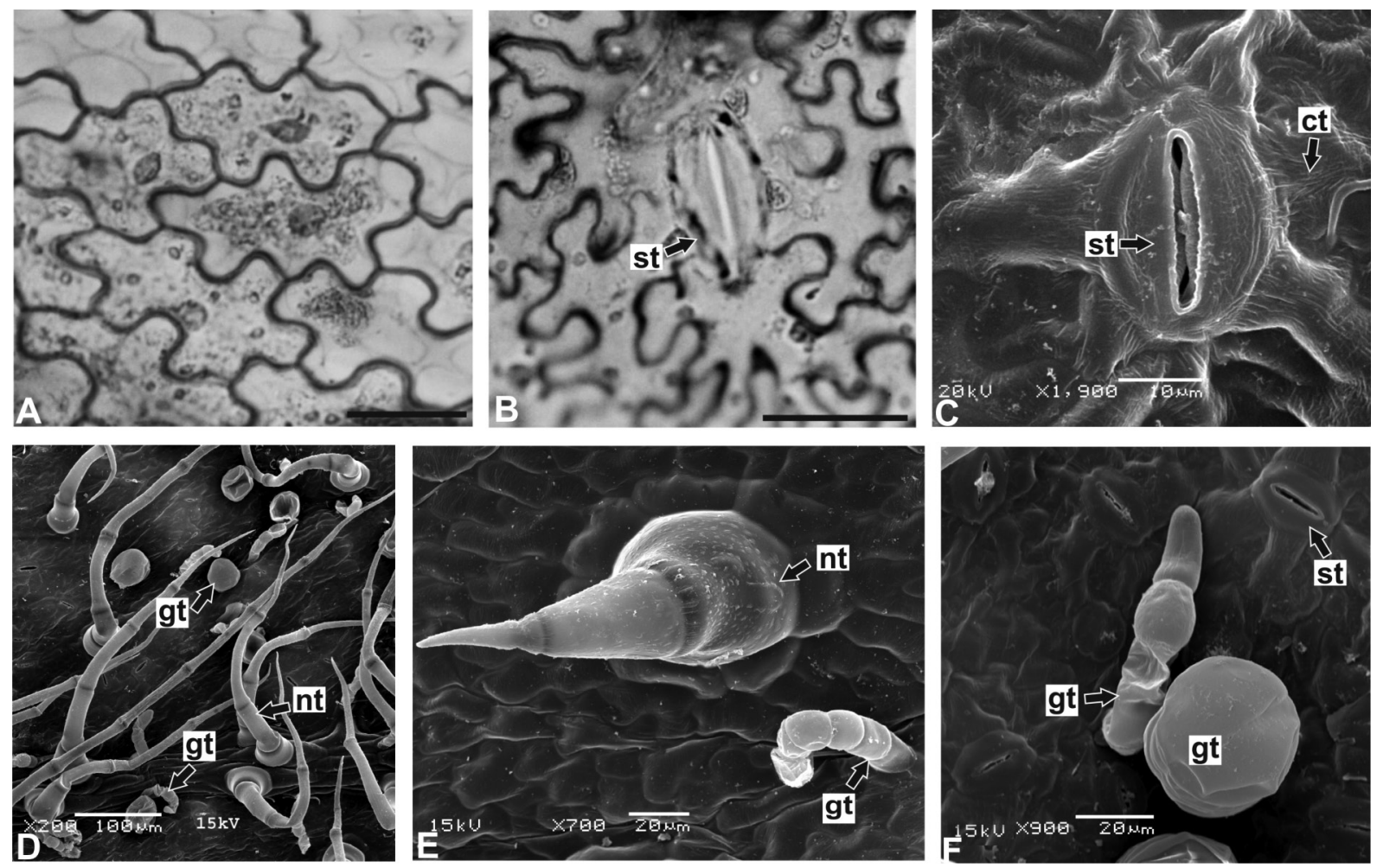

FIGURE 2 - A-F: Tithonia diversifolia (Hemsl.) A. Gray - leaf blade in surface view: A. Adaxial side; B. Abaxial surface, showing a stomatum; C. Detail of a stomatum and the slightly striated cuticle; D-F. Glandular and non-glandular trichomes. Abbreviations: ct - cuticle, gt - glandular trichome, $\mathbf{n t}$ - non-glandular trichome, st - stomatum. Bar $=20 \mu \mathrm{m}(\mathrm{A}, \mathrm{B})$.

on both surfaces. There are glandular and non-glandular trichomes (Figures 2D-2F) predominantly on the abaxial side. The latter (Figures 2D, 2E) are multicellular, consisting of three to eight cells in a single rank, with acute apex, larger base and relatively thick cell walls, and coated with a granular cuticle. The glandular trichomes secrete lipophilic substances and are of two types. The capitate type (Figures 2D, 2F) have a short and multicellular stalk and ovate and biseriate head. The non-capitate trichomes (Figures 2E, 2F) are bent, multicellular (three to six cells), and uniseriate with round apex.

In transverse section, the epidermis is uniseriate, with comparatively larger cells on the adaxial side (Figures 3A, 3D), due to slightly higher anticlinal walls. Stomata are located on the same level as the surrounding cells and the guard-cells show evident outer cuticular ledges. The mesophyll is dorsiventral (Figures 3A, 3D), encompassing two or three layers of palisade parenchyma and four to six rows of spongy parenchyma, which represents around $50 \%$ of the chlorenchyma height. Minor collateral vascular bundles are found encircled by a parenchymatic sheath (endodermis with no evident Casparian strips). Some of these bundles can present parenchymatic bundle-sheath extensions (Figure 3D).
The midrib has a biconvex shape in transverse section, showing a prominent curvature on the abaxial side (Figure 3A). Angular collenchyma are found adjacent to the epidermis (Figure 3B), consisting of eight to ten strata on the adaxial side and two or three layers on the abaxial side. Several vascular bundles, collateral with fascicular cambium, ovate and arranged as a ring traverse the ground parenchyma. There are one major, around six medium-size and two small bundles (Figures 3A-3C). Various secretory ducts (Figures 3B, 3C) presenting uniseriate epithelium, often aligned by four cells, with dense cytoplasm, evident nucleus and secreting lipophilic substances, are found proximal to the vascular bundles.

The petiole has a plano-convex contour, with small lateral wings in the distal region. It exhibits uniseriate epidermis, a continuous angular collenchyma (seven to ten layers), and secretory ducts near vascular bundles (Figure $3 \mathrm{E})$. These are collateral with fascicular cambium and arranged in an open arc in the proximal region and as a ring in the distal region.

The stem, in transverse section, has a circular shape and exhibits incipient secondary growth. The epidermis is uniseriate (Figures 4B, 4C) and may be detaching as the superficial development of the phellogen, which has 

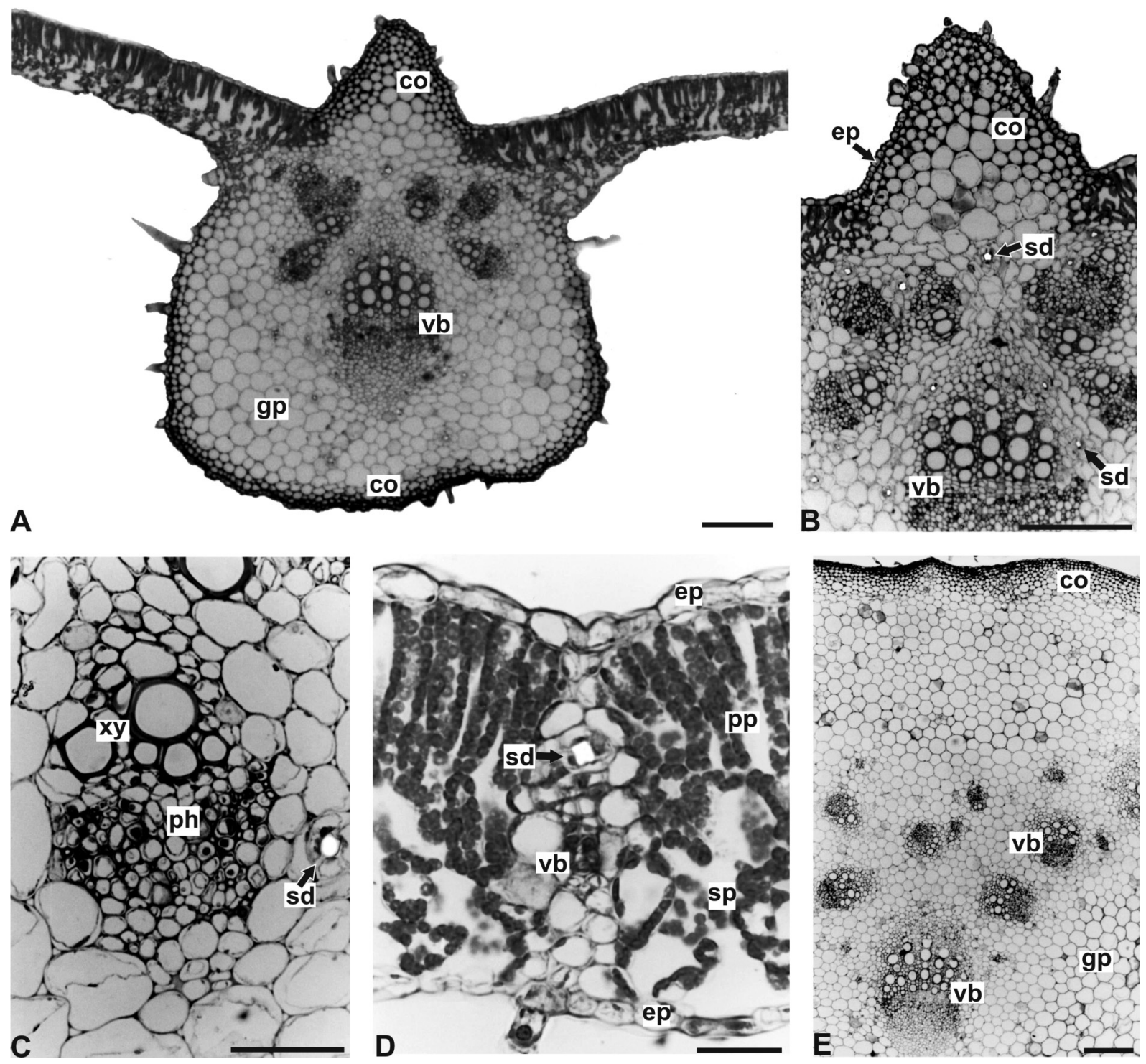

FIGURE 3 - A-E: Tithonia diversifolia (Hemsl.) A. Gray - leaf in transverse section: A. Intervein region and midrib with biconvex contour; B. Epidermis, collenchyma and vascular bundles in the midrib; C. Detail of a collateral vascular bundle and a secretory duct; D. Intervein region, displaying dorsiventral mesophyll and minor vascular bundle; E. Petiole. Abbreviations: co-collenchyma, ep - epidermis, $\mathbf{g p ~ - ~ g r o u n d ~ p a r e n c h y m a , ~} \mathbf{p h}$ - phloem, pp - palisade parenchyma, $\mathbf{s d ~ - ~ s e c r e t o r y ~ d u c t , ~} \mathbf{s p}$ - spongy parenchyma, $\mathbf{v b}-$ vascular bundle, $\mathbf{x y}-$ xylem. Bar $=200 \mu \mathrm{m}(\mathrm{A}, \mathrm{B}, \mathrm{E}), 20 \mu \mathrm{m}(\mathrm{C}, \mathrm{D})$.

subepidermal origin (Figure 4C). It follows a continuous strand of angular-tangential collenchyma (about six strata), multiseriate cortical parenchyma and an evident endodermis (Figure 4B) presenting Casparian strips. In the vascular cylinder, collateral vascular bundles with a cambial zone can be distinguished (Figure 4B). Sclerenchymatic caps adjoin the phloem (Figures 4A, 4B) and secretory ducts (Figure 4C), similar to those of the leaf, are found adjacent to the phloem and in the pith, typically near the xylem. A few small druses of calcium oxalate are seen in the pith as well as the ground parenchyma of the midrib.

\section{DISCUSSION}

The microscopic characteristics of the leaf and stem of $T$. diversifolia are in concordance with the general aspects of Asteraceae. Therefore, amphistomatous leaf with predominantly anomocytic stomata, uniseriate epidermis whose cells are sinuous in surface view, dorsiventral mesophyll and collateral vascular bundles were also reported in Vernonia condensata Baker (Barreto, Alves, Neves, 1994), Bidens pilosa L. (Duarte, Estelita, 1999), Mikania conferta Gardner (Oliveira, Rodrigues, Kato, 1999) and Taraxacum officinale F.H. Wigg. (Alquini, Takemori, 2000). 

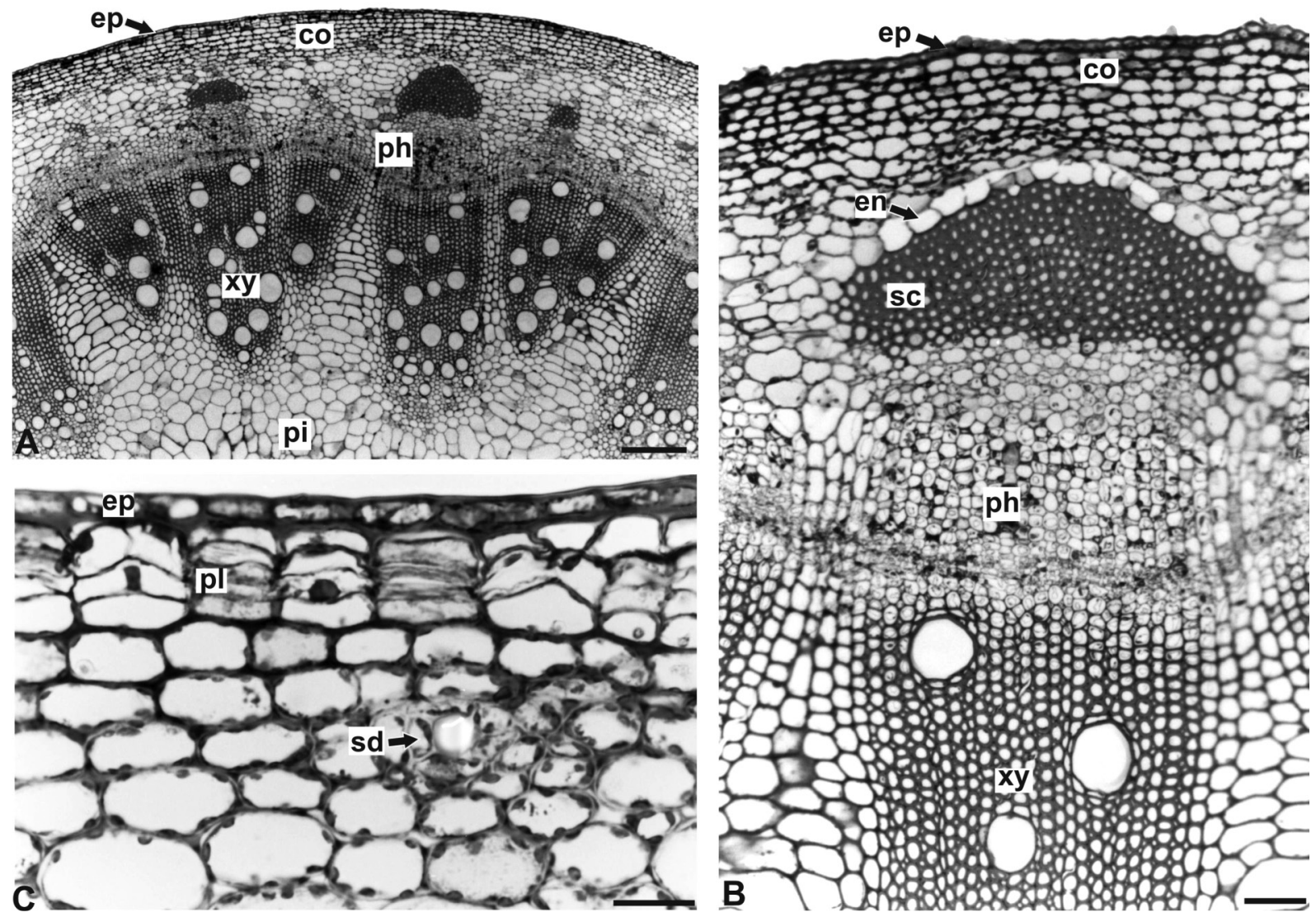

FIGURE 4 - A-C: Tithonia diver/sifolia (Hemsl.) A. Gray - stem in transverse section: A. Overall organization; B. Epidermis, cortex and vascular cylinder aspect; $\mathbf{C}$. Detail of the superficial phellogen onset. Abbreviations: co - collenchyma, en - endodermis, ep - epidermis, ph - phloem, pl - phellogen, sc - sclerenchymatic cap, sd - secretory duct, $\mathbf{x y}$ - xylem. Bar $=200 \mu \mathrm{m}(\mathrm{A}), 50 \mu \mathrm{m}$ (B), $20 \mu \mathrm{m}(\mathrm{C})$.

The leaf cuticle ornamentation, a relevant character for diagnosis (Metcalfe, Chalk, 1988), is described herein as slightly striated, akin to other species studied by different authors, for example, Calea longifolia Gardner (Farago et al., 2006), Mikania laevigata Sch. Bip. ex Baker (Budel et al., 2009) and Baccharis singularis (Vell.) G.M. Barroso (Souza et al., 2011).

Regarding trichomes, these are of three types in $T$. diversifolia. The non-glandular trichomes are multicellular and coated with a cuticle which exhibits granular microornamentation. These were also observed in B. pilosa (Duarte, Estelita, 1999), Ageratum conyzoides L. (Ferreira et al., 2002) and different species of Mikania (Rodrigues, Oliveira, Kato, 1996; Oliveira, Rodrigues, Kato, 1999; Oliveira et al., 2000). Among the glandular trichomes of $T$. diversifolia, there are both capitate and non-capitate types. The former are biseriate and were also reported in Santolina leucantha Bertol. (Pagni, Masini, 1999) and Tanacetum parthenium (L.) Sch. Bip. (Simmons, Krishna-Raj, Saxena, 2002). The non-capitate trichomes are uniseriate and bent, and were also mentioned in Bidens, Calea, Eupatorium, Verbesina
(Castro, Leitão-Filho, Monteiro, 1997) and Mikania (Rodrigues, Oliveira, Kato, 1996; Oliveira, Rodrigues, Kato, 1999; Oliveira et al., 2000). Although these trichomes are not exclusive in $T$. diversifolia, the simultaneous presence of the three types contributes to its identification. The same trichomes were described for the same species by Sasikala and Narayanan (1998) and play an important role in ecological interactions. Ambrósio et al. (2008) stated that glandular trichomes of $T$. diversifolia store sesquiterpene lactones as main constituents and act as an antimicrobial defense and antifeedant agent for caterpillars.

In general, the midrib plays an important role in distinguishing species. Tithonia diversifolia showed a biconvex midrib, in transverse section, and various vascular bundles in a circular arrangement. In comparison with other medicinal plants of the Heliantheae tribe, since scant information is available on the genus Tithonia, the midrib of C. longifolia has a concave-convex contour (Farago et al., 2006). Although having a biconvex shape, Calea uniflora Less. has one single vascular bundle (Budel et al., 2006).

Concerning the stem features, the results of this 
work were similar to the description published for the same species by Liasu and Ogunkunle (2007). These authors reported the occurrence of persistent epidermis, angular collenchyma and collateral vascular bundles with a strip of cambial cells, however without remarking on the phellogen initiation or endodermis description. According to Van Fleet (1961) and Mauseth (1988), the typical endodermis with evident Casparian strips, as seen in this study, is an important diagnostic character, being less frequent in stem than in root. The sclerenchymatic caps adjoining the phloem, observed in T. diversifolia in this work, were also seen in the investigation of Liasu and Ogunkunle (2007) and may be related to the pericyclic fibre strands mentioned by Melo-de-Pinna and Menezes (2002) in Asteraceae stems.

The secretory ducts of Asteraceae, according to Castro, Leitão-Filho and Monteiro (1997), present a single-layered epithelium. Pagni and Masini (1999) suggested that they are schizogenous. For the leaf, in some representatives of the Heliantheae tribe such as Aspilia, Bidens and Calea (Castro, Leitão-Filho, Monteiro, 1997), ducts were found next to the phloem and xylem, in the same manner as T. diversifolia. In this investigation of the stem, these secretory structures were found near the vascular system, in the cortex and pith.

For identification purposes, the characteristics of T. diversifolia described herein should be taken together, with emphasis on the different types of trichomes, the midrib features and localization of the secretory ducts, since isolated characters can also be present in other species of the group.

\section{ACKNOWLEDGEMENTS}

Thanks are due to the Centro de Microscopia Eletrônica (CME-UFPR) for providing the ultrastructural analysis and the taxonomists of the Museu Botânico Municipal de Curitiba for the species identification.

\section{REFERENCES}

ALQUINI, Y.; TAKEMORI, N.K. Organização estrutural de espécies vegetais de interesse farmacológico. Curitiba: Herbarium, 2000. 79 p.

AMBRÓSIO, S.R.; OKI, Y.; HELENO, V.C.G.; CHAVES, J.S.; NASCIMENTO, P.G.B.D.; LICHSTON, J.E.; CONSTANTINO, M.G.; VARANDA, E.M.; COSTA, F.B. Constituents of glandular trichomes of Tithonia diversifolia: relationships to herbivory and antifeedant activity. Phytochemistry, v.69, n.10, p.2052-2060, 2008.
BARRETO, M.A.; ALVES, V.F.G.; NEVES, L.J. Contribuição ao estudo de Vernonia condensata Baker. Rev. Bras. Farm., v.75, n.3, p.54-58, 1994.

BERLYN, G.P.; MIKSCHE, J.P. Botanical microtechnique and cytochemistry. Ames: Iowa State University Press, 1976. $326 \mathrm{p}$.

BUDEL, J.M.; DUARTE, M.R.; KOSCIUV, I.; MORAIS, T.B.; FERRARI, L.P. Contribuição ao estudo farmacognóstico de Mikania laevigata Sch. Bip. ex Baker (guaco), visando o controle de qualidade da matéria-prima. Rev. Bras. Farmacogn., v.19, n.2b, p.545-552, 2009.

BUDEL, J.M.; DUARTE, M.R.; PAULO, V.F.; TAKEDA, I.J.M. Caracteres anatômicos de folha e caule de Calea uniflora Less., Asteraceae. Rev. Bras. Farmacogn., v.16, n.1, p.53-60, 2006.

CASTRO, M.M.; LEITÃO-FILHO, H.F.; MONTEIRO, W.R. The use of secretory structures for identification of genera of Asteraceae from cerrado vegetation. Rev. Bras. Bot., v.20, n.2, p.163-174, 1997.

CHIANG, L.C.; CHENG, H.Y.; CHEN, C.C.; LIN, C.C. In vitro anti-leukemic and antiviral activities of traditionally used medicinal plants in Taiwan. Am. J. Chin. Med., v.32, n.5, p.695-704, 2004.

COS, P.; HERMANS, N.; BRUYNE, T.; APERS, S.; SINDAMBIWE, J.B.; WITVROUW, M.; CLERCQ, E.; VANDEN-BERGHE, D.; PIETERS, L.; VLIETINCK, A.J. Antiviral activity of Rwandan medicinal plants against human immunodeficiency virus type-1 (HIV-1). Phytomedicine, v.9, n.1, p.62-68, 2002.

DUARTE, M.R.; ESTELITA, M.E. Caracteres anatômicos de Bidens pilosa L., Asteraceae. Hoehnea, v.26, n.1, p.15-27, 1999.

DUKE, J.C. Revision of Tithonia. Rhodora, v.84, n.84, p.453$522,1982$.

ELUFIOYE, T.O.; AGBEDAHUNSI, J.M. Antimalarial activities of Tithonia diversifolia (Asteraceae) and Crossopteryx febrifuga (Rubiaceae) on mice in vivo. $J$. Ethnopharmacol., v.93, n.2/3, p.167-171, 2004. 
FARAGO, P.V.; BUDEL, J.M.; DUARTE, M.R.; JURGENSEN, I.; TAKEDA, I.J.M. Anatomia da folha e do caule de Calea longifolia (Asteraceae). Acta Farm. Bonaerense, v.25, n.4, p.512-517, 2006.

FERREIRA, E.A.; PROCÓPIO, S.O.; SILVA, E.A.M.; SILVA, A.A.; RUFINO, R.J.N. Estudos anatômicos de folhas de espécies de plantas daninhas. II. Bidens pilosa, Emilia sonchifolia, Ageratum conyzoides e Sonchus asper. Planta Daninha, v.20, n.3, p.327-335, 2002.

FOSTER, A. S. Practical plant anatomy. New York: D. Van Nostrand, 1949. 228 p.

GBOLADE, A.A.; BIONDI, D.M.; RUBERTO, G. Comparative analysis of the essential oil from two Asteraceous plants found in Nigeria, Acanthospermum hispidum and Tithonia diversifolia. Nat. Prod. Commun., v.3, n.10, p.1735-1738, 2008 .

GOFFIN, E.; ZIEMONS, E.; MOL, P.; MADUREIRA, M.C.; MARTINS, A.P.; CUNHA, A.P.; PHILIPPE, G.; TITS, M.; ANGENOT, L.; FRÉDÉRICH, M. In vitro antiplasmodial activity of Tithonia diversifolia and identification of its main active constituent: tagitinin C. Planta Med., v.68, n.6, p.543-545, 2002.

GU, J.Q.; GILLS, J.J.; PARK, E.J.; MATA-GREENWOOD, E.; HAWTHORNE, M.E.; AXELROD, F.; CHAVEZ, P.I.; FONG, H.H.S.; MEHTA, R.G.; PEZZUTO, J.M.; KINGHORN, A.D. Sesquiterpenoids from Tithonia diversifolia with potential cancer chemopreventive activity. J. Nat. Prod., v.65, n.4, p.532-536, 2002.

HEINRICH, M.; ANKLI, A.; FREI, B.; WEIMANN, C.; STICHER, O. Medicinal plants in Mexico: healers' consensus and cultural importance. Soc. Sci. Med., v.47, n.11, p.1859-1871, 1998.

HUI, H.; TANG, G.; GO, V.L.W. Hypoglycemic herbs and their action mechanims. Chinese Med., v.4, n.1, p.11-21, 2009.

JOHANSEN, D.A. Plant microtechnique. New York: McGrawHill Book, 1940. 523 p.

KRAUS, J.E.; ARDUIN, M. Manual básico de métodos em morfologia vegetal. Rio de Janeiro: Edur, 1997. 198 p.
KURODA, M.; YOKOSUKA, A.; KOBAYASHI, R.; JITSUNO, M.; KANDO, H.; NOSAKA, K.; ISHII, H.; YAMORI, T.; MIMAKI, Y. Sesquiterpenoids and flavonoids from the aerial parts of Tithonia diversifolia and their cytotoxic activity. Chem. Pharm. Bull., v.55, n.8, p.1240-1244, 2007.

LIASU, M.O.; OGUNKUNLE, A.T.J. Anatomy and secondary thickening pattern of the stem in Tithonia diversifolia (Hemsl) A. Gray. Adv. Nat. Appl. Sci., v.1, n.1, p.21-25, 2007.

MADUREIRA, M.C.; MARTINS, A.P.; GOMES, M.; PAIVA, J.; CUNHA, A.P.; ROSÁRIO, V. Antimalarial activity of medicinal plants used in traditional medicine in S. Tomé and Príncipe islands. J. Ethnopharmacol., v.81, n.1, p.23$29,2002$.

MAREGESI, S.M.; NGASSAPA, O.D.; PIETERS, L.; VLIETINCK, A.J. Ethnopharmacological survey of the Bunda district, Tanzania: plants used to treat infectious diseases. J. Ethnopharmacol., v.113, n.3, p.457-470, 2007.

MAREGESI, S.M.; VAN MIERT, S.; PANNECOUQUE, C.; FEIZ-HADDAD, M.H.; HERMANS, N.; WRIGHT, C.W.; VLIETINCK, A.J.; APERS, S.; PIETERS, L. Screening of Tanzanian medicinal plants against Plasmodium falciparum and human immunodeficiency virus. Planta Med., v.76, n.2, p.195-201, 2009.

MAUSETH, J.D. Plant anatomy. Menlo Park: Benjamin/ Cummings, 1988.560 p.

MELO-DE-PINNA, G.F.A.; MENEZES, N.L. Vegetative organ of Ianthopappus corymbosus Roque \& Hind (AsteraceaeMutiseae). Rev. Bras. Bot., v.25, n.4, p.505-514, 2002.

METCALFE, C.R.; CHALK, L. Anatomy of the dicotyledons: systematic anatomy of the leaf and stem. Oxford: Clarendon, 1988. $276 \mathrm{p}$.

MIURA, T.; FURUTA, K.; YASUDA, A.; IWAMOTO, N.; KATO, M.; ISHIHARA, E.; ISHIDA, T.; TANIGAWA, K. Antidiabetic effect of nitobegiku in KK-Ay diabetic mice. Am. J. Chin. Med., v.30, n.1, p.81-86, 2002.

MIURA, T.; NOSAKA, K.; ISHII, H.; ISHIDA, T. Antidiabetic effect of nitobegiku, the herb Tithonia diversifolia, in KKAy diabetic mice. Biol. Pharm. Bull., v.28, n.11, p.21522154, 2005. 
MUGANGA, R.; ANGENOT, L.; TITS, M.; FRÉDÉRICH, M. Antiplasmodial and cytotoxic activities of Rwandan medicinal plants used in the treatment of malaria. $J$. Ethnopharmacol., v.128, n.1, p.52-57, 2010.

NJOROGE, G.N.; BUSSMANN, R.W. Diversity and utilization of antimalarial ethnophytotherapeutic remedies among the Kikuyus (Central Kenya). J. Ethnobiol. Ethnomed., v.2, n.1, p.8-14, 2006a.

NJOROGE, G.N.; BUSSMANN, R.W. Traditional management of ear, nose and throat (ENT) diseases in Central Kenya. $J$. Ethnobiol. Ethnomed., v.2, n.1, p.54-62, 2006 b.

O'BRIEN, T.P.; FEDER, N.; McCULLY, M.E. Polychromatic staining of plant cell walls by toluidine blue O. Protoplasma, v.59, n.2, p.368-373, 1964.

OLIVEIRA, F; AKISUE, G. Fundamentos de farmacobotânica. São Paulo: Atheneu, 1997. 178 p.

OLIVEIRA, F.; RODRIGUES, R.F.O.; BASTOS, D.H.M.; PEREIRA, F.H. Caracterização morfohistológica e verificação da atividade microbiológica da espécie vegetal Mikania cordifolia (L. f.) Willd. Lecta, v.18, n.1, p.33-63, 2000.

OLIVEIRA, F.; RODRIGUES, R.F.O.; KATO, E.T.M. Estudo farmacognóstico da almécega-da-praia: Mikania conferta Gardn. Lecta, v.17, n.2, p.43-68, 1999.

OWOYELE, V.B.; WURAOLA, C.O.; SOLADOYE, A.O.; OLALEYE, S.B. Studies on the anti-inflammatory and analgesic properties of Tithonia diversifolia leaf extract. $J$. Ethnopharmacol., v.90, n.2/3, p.317-321, 2004.

PAGNI, A.M.; MASINI, A. Morphology, distribution, and histochemistry of secretory structures in vegetative organs of Santolina leucantha Bertol. (Asteraceae). Israel J. Plant Sci., v.47, n.4, p.257-263, 1999.

PEREIRA, P.S.; DIAS, D.A.; VICHNEWSKI, W.; NASI, A.M.T.T.; HERZ, W. Sesquiterpene lactones from Brazilian Tithonia diversifolia. Phytochemistry, v.45, n.7, p.14451448, 1997.

RODRIGUES, R.F.O.; OLIVEIRA, F.; KATO, E.T.M. Morfodiagnose da droga conhecida como cipó-almécega Mikania malacolepsis Robinson. Rev. Farm. Bioquím. Univ. S. Paulo, v.32, n.1, p.37-44, 1996.
ROESER, K.R. Die Nadel der Schwarzkiefer-Masenprodukt und Kunstwerk der Natur. Mikrokosmos, v.61, n.2, p.33$36,1972$.

RÜNGELER, P.; LYSS, G.; CASTRO, V.; MORA, G.; PAHL, H.L.; MERFORT, I. Study of three sesquiterpene lactones from Tithonia diversifolia on their anti-inflammatory activity using the transcription factor NF-kappa B and enzymes of the arachidonic acid pathway as targets. Planta Med., v.64, n.7, p.588-593, 1998.

SASIKALA, K.; NARAYANAN, R. Numerical evaluation of trichome characters in certain members of Asteraceae. Phytomorphology, v.48, n.1, p.67-81, 1998.

SASS, J.E. Botanical microtechnique. Ames: Iowa State College Press, 1951. 228 p.

SIMMONS, C.B.; KRISHNA-RAJ, S.; SAXENA, P.K. Morphocytological characterization of feverfew, Tanacetum parthenium (L.) Schultz Bip. J. Herbs Spices Med. Plants, v.9, n.1, p.29-45, 2002.

SOUZA, C.A.; FARAGO, P.V.; DUARTE, M.R.; BUDEL, J.M. Pharmacobotanical study of Baccharis singularis (Vell.) G.M. Barroso, Asteraceae. Latin Am. J. Pharm., v.30, n.2, p.311-317, 2011.

SOUZA, W. Técnicas básicas de microscopia eletrônica aplicadas às Ciências Biológicas. Rio de Janeiro: Sociedade Brasileira de Microscopia Eletrônica, 1998. 179 p.

TONA, L.; KAMBU, K.; NGIMBI, N.; CIMANGA, K.; VLIETINCK, A.J. Antiamoebic and phytochemical screening of some Congolese medicinal plants. $J$. Ethnopharmacol., v.61, n.1, p.57-65, 1998.

TONA, L.; KAMBU, K.; NGIMBI, N.; MESIA, K.; PENGE, O.; LUSAKIBANZA, M.; CIMANGA, K.; BRUYNE, T.; APERS, S.; TOTTE, J.; PIETERS, L.; VLIETINCK, A.J. Antiamoebic and spasmolytic activities of extracts from some antidiarrhoeal traditional preparations used in Kinshasa, Congo. Phytomedicine, v.7, n.1, p.31-38, 2000.

VAN FLEET, D.S. Histochemistry and function of the endodermis. Bot. Rev., v.27, n.2, p.165-220, 1961.

Received for publication on $15^{\text {th }}$ June 2011 Accepted for publication on $30^{\text {th }}$ November 2011 